\title{
Syntheses, molecular and crystalline architectures, and luminescence behaviour of terephthalate bridged heptacoordinated dinuclear lead(II) complexes containing a pentadentate $\mathrm{N}$-donor Schiff base
}

\author{
SUBHASIS ROY ${ }^{\mathrm{a}}$, SOMNATH CHOUBEY ${ }^{\mathrm{a}}$, SUMITAVA KHAN ${ }^{\mathrm{a}}$, KISHALAY BHAR ${ }^{\mathrm{a}}$, \\ PARTHA MITRA $^{\mathrm{b}}$ and BARINDRA KUMAR GHOSH ${ }^{\mathrm{a}, *}$ \\ a Department of Chemistry, The University of Burdwan, Burdwan 713 104, India \\ ${ }^{b}$ Department of Inorganic Chemistry, Indian Association for the Cultivation of Science, Kolkata 700 032, India \\ e-mail: barin_1@yahoo.co.uk
}

MS received 18 September 2012; revised 20 December 2012; accepted 18 January 2013

\begin{abstract}
One-pot synthesis using a 2:2:1:2 molar ratio of $\mathrm{Pb}(\mathrm{OAc})_{2} \cdot 3 \mathrm{H}_{2} \mathrm{O}$, L, piperidinum terephthalate (ptp) and $\mathrm{NaClO}_{4} / \mathrm{NH}_{4} \mathrm{PF}_{6}$ at room temperature affords two dinuclear compounds of the type $\left[\mathrm{Pb}_{2}(\mathrm{~L})_{2}(\mu-\right.$ tp) $]\left(\mathrm{ClO}_{4} / \mathrm{PF}_{6}\right)_{2}(\mathbf{1 / 2})\left[\mathrm{L}=\mathrm{N}, \mathrm{N}^{\prime}\right.$-(bis-(pyridin-2-yl)benzylidene)diethylenetriamine and tp = terephthalate dianion]. The compounds are characterized by microanalytical, spectroscopic, thermal and other physicochemical results. X-ray structural analyses of $\mathbf{1}$ and $\mathbf{2}$ reveal that each heptacoordinated lead(II) centre with a $\mathrm{PbN}_{5} \mathrm{O}_{2}$ chromophore are bound by five $\mathrm{N}$ atoms of $\mathrm{L}$ and connected through $\mathrm{O}$ atoms of a bis(bidentate) tp bridge. The arrangements of $\mathrm{L}$ and tp suggest a gap around the metal centre due to occupation of a stereo-active lone pair of electrons reflecting a hemidirected coordination around the metal centre. The complexes exhibit reasonable thermal stabilities with the tolerate temperatures ca. $255^{\circ} \mathrm{C}$ for $\mathbf{1}$ and $263^{\circ} \mathrm{C}$ for 2 . The complexes display intraligand $\left(\pi-\pi^{*}\right)$ fluorescence in the solid state and in DMF solutions at room temperature.
\end{abstract}

Keywords. Dinuclear lead(II); Schiff base; terephthalate bridge; hemidirected structures; luminescence.

\section{Introduction}

Mono-, di- and polynuclear lead(II) complexes ${ }^{1-18}$ have potential applications as catalysts, porous materials, gas storages, nonlinear optical materials and luminescent devices. ${ }^{7,8,19-24}$ The compounds with coordination numbers two to five show hemidirected ${ }^{1,2,13-16}$ metal ligand coordination, whereas holodirected coordination $^{1,15,16}$ environments are found for higher coordination numbers, nine and ten. Either ${ }^{1,16}$ of these two irregular coordination environments is found with coordination numbers six to eight. Schiff bases, ${ }^{18,25-28}$ have been widely used as end-capping ligands affording different functional materials with interesting molecular aggregates and crystalline architectures. We have reported some lead(II) pseudohalide complexes ${ }^{17,18}$ in combination with Schiff bases; interesting synthetic, structural and luminescent properties of these compounds have prompted us to explore the chemistry of lead(II) in combination with Schiff bases and aromatic dicarboxylates ${ }^{5,10,11,13-16}$ such as terephthalate (tp). ${ }^{12-16}$

*For correspondence
The syntheses, structures, and thermal and luminescence behaviours of two hemidirected compounds $\left[\mathrm{Pb}_{2}(\mathrm{~L})_{2}(\mu\right.$-tp) $]\left(\mathrm{ClO}_{4} / \mathrm{PF}_{6}\right)_{2}(\mathbf{1} / \mathbf{2})\left[\mathrm{L}=\mathrm{N}, \mathrm{N}^{\prime}\right.$-(bis-(pyridin2-yl)benzylidene)diethylenetriamine; scheme 1] are described below.

\section{Experimental}

\subsection{Materials}

High purity diethylenetriamine (Spectrochem, India), 2-benzoylpyridine (Lancaster, UK), terephthalic acid (Loba Chemie, India), piperidine (Loba Chemie, India), lead(II) acetate (E Merck, India), sodium perchlorate (Lancaster, UK) and ammonium hexaflurophosphate (Fluka, Germany) were purchased and were used as received. Schiff base, N,N'-(bis-(pyridin-2yl)benzylidene)diethylenetriamine (L) was prepared by condensation of 1:2 molar ratio of diethylenetriamine and 2-benzoylpyridine using a reported method. ${ }^{27}$ Piperidinium terephthalate (ptp) was isolated by following a method described elsewhere. ${ }^{29}$ All other chemicals and solvents used were AR grade. 


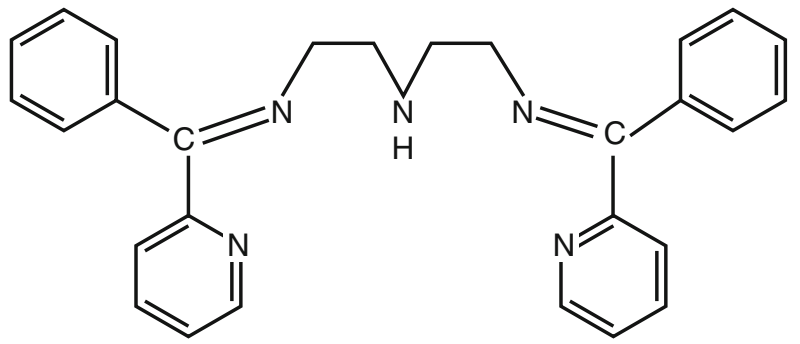

(L)

Scheme 1. Framework of pentadentate N-donor Schiff base (L).

\subsection{Physical measurements}

Elemental analyses were performed on a Perkin-Elmer $2400 \mathrm{CHNS} / \mathrm{O}$ elemental analyser. IR spectra $(\mathrm{KBr}$ discs, 4000-400 $\mathrm{cm}^{-1}$ ) were recorded using a PerkinElmer FTIR model RX1 spectrometer. Molar conductances were measured using a Systronics conductivity meter where the cell constant was calibrated with $0.01 \mathrm{M} \mathrm{KCl}$ solution and dry $\mathrm{MeCN}$ was used as solvent. Thermal behaviours were examined with a Perkin-Elmer Diamond TG/DT analyser heated from 40 to $700^{\circ} \mathrm{C}$ under dinitrogen. Ground state absorptions (in dry $\mathrm{N}, \mathrm{N}$-dimenthylformamide [DMF]) were made with a Shimadzu model UV-2450 UV-Vis spectrophotometer. Steady-state fluorescence measurements were done using Hitachi model F-4500 spectrofluorimeter.

\subsection{Preparation of the complexes}

Compounds 1 and $\mathbf{2}$ were obtained from methanolic solutions using a 2:2:1:2 molar ratio of lead(II) acetate, Schiff base (L), ptp and $\mathrm{NaClO}_{4} / \mathrm{NH}_{4} \mathrm{PF}_{6}$ as appropriate. All the reactions were performed using selfassembly at room temperature and were reproducible. The typical syntheses of the compounds are described below.

2.3a Syntheses of $\left[\mathrm{Pb}_{2}(\mathrm{~L})_{2}(\mu-t p)\right]\left(\mathrm{ClO}_{4}\right)_{2} \quad$ (1) and $\left[P b_{2}(L)_{2}(\mu-t p)\right]\left(P F_{6}\right)_{2}(2): \quad L(0.086 \mathrm{~g}, 0.2 \mathrm{mmol})$ in methanol $(10 \mathrm{~mL})$ was added dropwise to a solution of $\mathrm{Pb}(\mathrm{OAc})_{2} .3 \mathrm{H}_{2} \mathrm{O}(0.076 \mathrm{~g}, 0.2 \mathrm{mmol})$ dissolved in the same solvent $(10 \mathrm{~mL})$. To this resulting faint yellow solution, a methanolic solution $(5 \mathrm{~mL})$ of ptp $(0.034 \mathrm{~g}, 0.1 \mathrm{mmol})$ was added slowly followed by $\mathrm{NaClO}_{4}(0.0281 \mathrm{~g}, 0.2 \mathrm{mmol})$ in methanol $(5 \mathrm{~mL})$. The final faint yellow solution was filtered through a glass-frit and left undisturbed in an open air for slow evaporation. After a week colourless microcrystals of $\mathbf{1}$ were collected and dried in vacuo over silica gel. Yield:
$1.31 \mathrm{~g}(80 \%)$. Compound 2 was prepared similarly using the same stoichiometry and reaction conditions except that $\mathrm{NH}_{4} \mathrm{PF}_{6}(0.0326 \mathrm{~g}, 0.2 \mathrm{mmol})$ instead of $\mathrm{NaClO}_{4}$ was used. Yield: $1.15 \mathrm{~g}(70 \%) .2$ was also isolated by metathesis of 1 with $\mathrm{NH}_{4} \mathrm{PF}_{6}$ in 1:2 ratio from a methanolic solution and constant stirring for $45 \mathrm{~min}$ at room temperature. The resulting yellow solution was processed as described above to afford pure 2 . The microanalytical and spectroscopic results for $\mathbf{2}$ obtained from both methods are akin which are listed here. Anal. Calc. for $\mathrm{C}_{64} \mathrm{H}_{58} \mathrm{~N}_{10} \mathrm{O}_{12} \mathrm{Cl}_{2} \mathrm{~Pb}_{2}$ (1): C, 46.7; H, 3.5; N, 8.51. Found: C, $47.5 ; \mathrm{H}, 3.7 ; \mathrm{N}, 8.3 \%$. IR $\left(\mathrm{KBr}, \mathrm{cm}^{-1}\right)$ : $v_{\text {as }}\left(\mathrm{COO}^{-}\right) 1584 ; v_{\mathrm{s}}\left(\mathrm{COO}^{-}\right) 1356 ; v(\mathrm{C}=\mathrm{N})+v$ $(\mathrm{C}=\mathrm{C}) 1624,1595 ; v\left(\mathrm{ClO}_{4}^{-}\right) 1085,623 . \Lambda_{\mathrm{M}}(\mathrm{MeCN}$, $\left.\mathrm{ohm}^{-1} \mathrm{~cm}^{2} \mathrm{~mol}^{-1}\right)$ : 235. UV-Vis $(\lambda, \mathrm{nm}): 269$. Yield: $1.21 \mathrm{~g} \mathrm{(70 \% ).} \mathrm{Anal.} \mathrm{Calc.} \mathrm{for} \mathrm{C}_{64} \mathrm{H}_{58} \mathrm{~N}_{10} \mathrm{O}_{4} \mathrm{~F}_{12} \mathrm{P}_{2} \mathrm{~Pb}_{2}(2)$ : C, 44.3; H, 3.4; N, 8.1. Found: C, 44.5; H, 3.1; N, 8.3\%. IR $\left(\mathrm{KBr}, \mathrm{cm}^{-1}\right): v_{\text {as }}\left(\mathrm{COO}^{-}\right) 1585 ; v_{\mathrm{s}}\left(\mathrm{COO}^{-}\right) 1358$; $v(\mathrm{C}=\mathrm{N})+v(\mathrm{C}=\mathrm{C})$ 1621, 1594; $v\left(\mathrm{PF}_{6}^{-}\right) 836,557$. $\Lambda_{\mathrm{M}}\left(\mathrm{MeCN}, \mathrm{ohm}^{-1} \mathrm{~cm}^{2} \mathrm{~mol}^{-1}\right): 230$. UV-Vis $(\lambda, \mathrm{nm})$ : 272.

\section{$2.4 X$-ray data collection and structure refinement}

Diffraction data of the single crystals of $\mathbf{1}$ and $\mathbf{2}$ were collected at $293 \mathrm{~K}$ on a Bruker AXS SMART APEXII CCD area-detector diffractometer using graphite monochromated Mo-K $\alpha$ radiation. The unit cell parameters were obtained from SAINT ${ }^{30}$ and absorption corrections were performed with SADABS. ${ }^{31}$ The structures were solved by direct methods using SHELXS-97 ${ }^{32}$ and refined by full-matrix least-squares method based on $F^{2}$ using SHELXL-97. ${ }^{32}$ All nonhydrogen atoms were refined with anisotropic displacement parameters. The hydrogen atoms were fixed geometrically and refined using a riding model. All calculations were carried out using SHELXTL, ${ }^{32}$ PLA$\mathrm{TON}^{33}$ and Mercury $2.3^{34}$ programs. A summary of the crystallographic data and structure determination parameters is given in table 1 .

\section{Results and discussion}

\subsection{Synthesis and formulation}

A 2:2:1:2 molar ratio of the building components at room temperature in methanol yielded heptacoordinated dinuclear compounds of type $\left[\mathrm{Pb}_{2}(\mathrm{~L})_{2}(\mu\right.$ tp)] $\left(\mathrm{ClO}_{4} / \mathrm{PF}_{6}\right)_{2}(\mathbf{1} / \mathbf{2})$. Compound 2 was also isolated by metathesis of 1 in methanol using $\mathrm{NH}_{4} \mathrm{PF}_{6}$. The reactions were reproducible as was evident from repetitive microanalytical results, spectral behaviours and other 
Table 1. Crystallographic data and structure refinement parameters in $\mathbf{1}$ and $\mathbf{2 .}$

\begin{tabular}{|c|c|c|}
\hline Compounds & 1 & 2 \\
\hline Chemical formula & $\mathrm{C}_{64} \mathrm{H}_{58} \mathrm{~N}_{10} \mathrm{O}_{12} \mathrm{Cl}_{2} \mathrm{~Pb}_{2}$ & $\mathrm{C}_{64} \mathrm{H}_{58} \mathrm{~N}_{10} \mathrm{O}_{4} \mathrm{~F}_{12} \mathrm{P}_{2} \mathrm{~Pb}_{2}$ \\
\hline Formula mass & 1644.48 & 1735.52 \\
\hline Crystal system & Monoclinic & Monoclinic \\
\hline Space group & $\mathrm{P} 21 / \mathrm{n}$ & $\mathrm{P} 21 / \mathrm{n}$ \\
\hline$a / \AA$ & $11.889(4)$ & $11.925(3)$ \\
\hline$b / \AA$ & $11.543(4)$ & $11.546(3)$ \\
\hline$c / \AA$ & $23.804(8)$ & $24.445(6)$ \\
\hline$\alpha /^{\circ}$ & 90 & 90 \\
\hline$\beta /{ }^{\circ}$ & $92.236(5)$ & 93.742(7) \\
\hline$\gamma /{ }^{\circ}$ & 90 & 90 \\
\hline $\mathrm{V} / \AA^{3}$ & $3264.5(18)$ & $3358.7(14)$ \\
\hline $\mathrm{T} / \mathrm{K}$ & 293(2) & 293(2) \\
\hline$\lambda / \AA$ & 0.71073 & 0.71073 \\
\hline Z & 2 & 2 \\
\hline$\mu / \mathrm{mm}^{-1}$ & 5.300 & 5.141 \\
\hline$D_{\text {calc }} / \mathrm{g} \mathrm{m}^{-3}$ & 1.673 & 1.716 \\
\hline 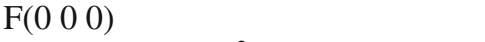 & 1612 & 1692 \\
\hline Crystal size $/ \mathrm{mm}^{3}$ & $0.18 \times 0.16 \times 0.14$ & $0.28 \times 0.22 \times 0.17$ \\
\hline$\theta$ ranges $/^{\circ}$ & 1.71 to 23.66 & 1.67 to 22.13 \\
\hline$h / k / l$ & $-13,13 /-12,13,-26,26$ & $-12,12 /-12,12,-25,25$ \\
\hline Reflections collected & 27545 & 23750 \\
\hline Independent reflections & 4909 & 4180 \\
\hline Data/restraints/parameters & $4909 / 0 / 406$ & $4180 / 0 / 424$ \\
\hline$R_{\text {int }}$ & 0.099 & 0.120 \\
\hline Final $R_{1}$ values $(I>2 \sigma(I))$ & 0.0447 & 0.0502 \\
\hline Final $w R\left(F^{2}\right)$ values $(I>2 \sigma(I))$ & 0.0910 & 0.1161 \\
\hline Final $R_{1}$ values (all data) & 0.0960 & 0.0896 \\
\hline Final $w R\left(F^{2}\right)$ values (all data) & 0.1123 & 0.1396 \\
\hline Goodness of fit on $F^{2}$ & 1.017 & 1.008 \\
\hline Largest peak and hole $\left(\mathrm{e} \AA^{-3}\right)$ & 0.770 and -0.656 & 0.836 and -0.706 \\
\hline
\end{tabular}

Weighting scheme: $\mathrm{R}=\Sigma|| \mathrm{Fo}|-| \mathrm{Fc}|| / \Sigma|\mathrm{Fo}|, \mathrm{wR}=\left[\Sigma \mathrm{w}\left(\mathrm{F}_{\mathrm{o}}^{2}-\mathrm{F}_{\mathrm{c}}^{2}\right)^{2} / \Sigma \mathrm{w}\left(\mathrm{F}_{\mathrm{o}}^{2}\right)^{2}\right]^{1 / 2}, \mathrm{calcd} \mathrm{w}=1 /\left[\sigma^{2}\left(\mathrm{~F}_{\mathrm{o}}^{2}\right)+\right.$ $\left.(\mathrm{xP})^{2}+\mathrm{yP}\right] ; \mathrm{x}=0.0464 \mathrm{P}$ (for 1), 0.0739 (for 2) and $\mathrm{y}=1.5647$ (for 1), 0.0000 (for 2)

physicochemical properties. The details of the reactions are summarized in Eqs. 1 and 2:

$$
\begin{gathered}
\mathrm{Pb}(\mathrm{OAc})_{2} \cdot 3 \mathrm{H}_{2} \mathrm{O}+\mathrm{L}+\mathrm{ptp}+\mathrm{NaClO}_{4} / \mathrm{NH}_{4} \mathrm{PF}_{6} \\
\stackrel{\mathrm{MeOH}}{\longrightarrow}\left[\mathrm{Pb}_{2}(\mathrm{~L})_{2}(\mu-\mathrm{tp})\right]\left(\mathrm{ClO}_{4} / \mathrm{PF}_{6}\right)_{2} \\
(\mathbf{1} / \mathbf{2})
\end{gathered}
$$

$$
\left[\mathrm{Pb}_{2}(\mathrm{~L})_{2}(\mu-\mathrm{tp})\right]\left(\mathrm{ClO}_{4}\right)_{2}
$$

(1)

$$
\stackrel{\mathrm{NH}_{4} \mathrm{PF}_{6}}{\longrightarrow}\left[\mathrm{Pb}_{2}(\mathrm{~L})_{2}(\mu-\mathrm{tp})\right]\left(\mathrm{PF}_{6}\right)_{2}
$$

The compounds were characterized using microanalytical, spectroscopic thermal and other physicochemical results. The microanalytical results are in conformity with formulations $\mathbf{1}$ and $\mathbf{2}$. The moisture- insensi- tive compounds are soluble in common organic solvents such as acetonitrile, dimethylformamide, dimethylsulphoxide, but are insoluble in water. MeCN solutions of $\mathbf{1}$ and $\mathbf{2}$ show conductivity values $\left[\Lambda_{\mathrm{M}}(\mathrm{MeCN}\right.$, $\mathrm{ohm}^{-1} \mathrm{~cm}^{2} \mathrm{~mol}^{-1}$ ): $235(\mathbf{1})$ and $\left.230(\mathbf{2})\right]$ corresponding to $2: 1$ electrolytic behaviour. ${ }^{35}$

\subsection{Spectroscopic features}

In IR spectra, the stretching vibrations of tp in $\mathbf{1}$ and 2 are seen as strong $v_{\mathrm{as}}\left(\mathrm{COO}^{-}\right)$and $v_{\mathrm{s}}\left(\mathrm{COO}^{-}\right)$absorptions at ca. $1585 \mathrm{~cm}^{-1}$ and ca. $1360 \mathrm{~cm}^{-1}$, respectively. The metal bound Schiff base (L) in complexes $\mathbf{1}$ and $\mathbf{2}$ show $v(\mathrm{C}=\mathrm{N})$ plus $v(\mathrm{C}=\mathrm{C})$ stretching frequencies ${ }^{36}$ at ca. 1625 and ca. $1595 \mathrm{~cm}^{-1}$. Several weak bands in the range $2970-2920 \mathrm{~cm}^{-1}$ assignable to aliphatic $v(\mathrm{C}-\mathrm{H})$ stretching vibration are routinely observed. The presence of perchlorate bands at 1085 and $623 \mathrm{~cm}^{-1}$ in 1 and hexafluorophosphate stretches at 836 and $557 \mathrm{~cm}^{-1}$ in 


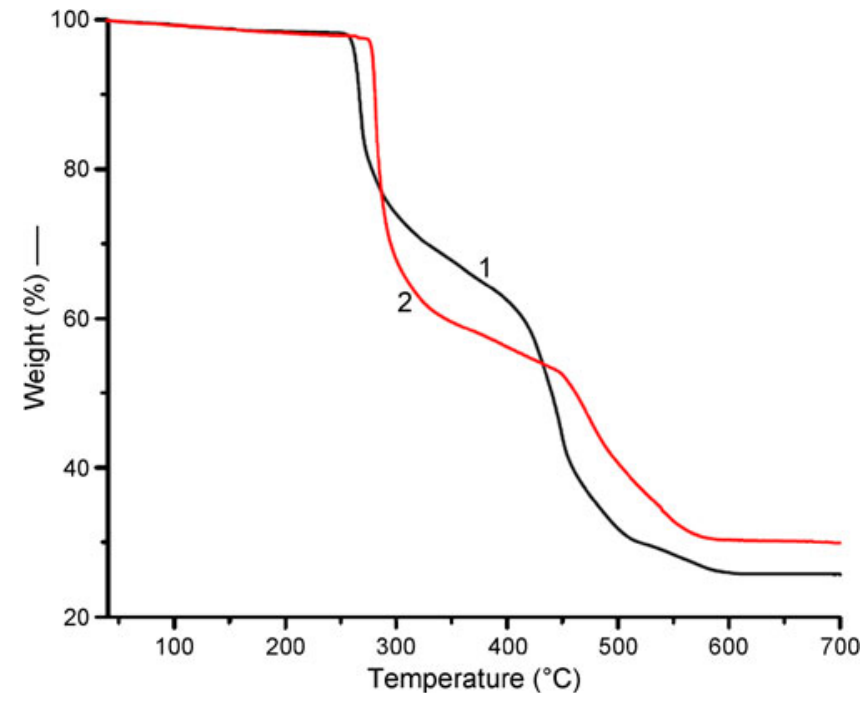

Figure 1. Thermal behaviours of $\mathbf{1}$ and 2 .

2 are noticed, reflecting counter anionic view ${ }^{36}$ with no metal coordination. In DMF solutions, $\mathrm{L}$ and ptp show absorption bands at $266 \mathrm{~nm}$ and $281 \mathrm{~nm}$, respectively whereas the corresponding lead(II) complexes exhibit bands at $269 \mathrm{~nm}$ (for 1) and $272 \mathrm{~nm}$ (for 2) assignable to ligand based $n-\pi^{*} / \pi-\pi^{*}$ charge transfer transition. ${ }^{37}$

\subsection{Thermal analysis}

Thermogravimetric and differential thermal analyses (TG-DTA) of compounds $\mathbf{1}$ and $\mathbf{2}$ were carried out to examine their thermal stabilities. The crushed singlecrystals of 1 and 2 were heated between 40 and $700^{\circ} \mathrm{C}$ temperature in the static atmosphere of dinitrogen at a heating rate of $10^{\circ} \mathrm{C} \mathrm{min}-1$. The TG curves (figure 1) show that both the compounds simultaneously loose two Schiff bases (for 1; obs.: $57.31 \%$, calc.: $57.16 \%$, for 2; obs.: $55.4 \%$, calc.: $53.92 \%$ ) in the first step of the pyrolysis process between the temperature range 255 $456^{\circ} \mathrm{C}$ in 1 and $263-483^{\circ} \mathrm{C}$ in 2 . The second step weight loss is associated with the removal of tp dianion (for $\mathbf{1}$; obs.: $14.46 \%$, calc.: $10.81 \%$, for 2 ; obs.: $11.27 \%$, calc.: $10.20 \%$ ) in both the compounds. The weight (for $\mathbf{1}$; obs.: $26.27 \%$, calc.: $27.20 \%$, for $\mathbf{2}$; obs.: $30.75 \%$, calc.: $25.77 \%$ ) of the final residue corresponds to two $\mathrm{PbO}$ units.

\subsection{Fluorescence properties}

The photoluminescence behaviours of the dicarboxylate (ptp) and the corresponding lead(II) compounds $\mathbf{1}$ and $\mathbf{2}$ are examined in DMF solutions and in solid state at room temperature ( $298 \mathrm{~K})$. The free Schiff base (L) is a gummy mass, so its fluorescence behaviour cannot be measured in solid state; however such study with its DMF solution is made. The spectral patterns are shown in figure $2 \mathrm{a}, \mathrm{b}$. Upon photoexcitation at the corresponding absorption bands ( $281 \mathrm{~nm}$ for ptp and $266 \mathrm{~nm}$ for $\mathrm{L}$ ) the DMF solutions of ptp and L exhibit a main fluorescent emission centred at $355 \mathrm{~nm}$ with a weak emission at $333 \mathrm{~nm}$, whereas $\mathbf{1}$ and $\mathbf{2}$ show two intense emission bands at ca. 330 and $360 \mathrm{~nm}$ upon excitation at 269 and $272 \mathrm{~nm}$, respectively. The luminescence behaviour in all cases may be attributed to an intraligand $(\pi \rightarrow$ $\left.\pi^{*}\right)$ emission. In the solid state ptp absorbs at $292 \mathrm{~nm}$ whereas the corresponding lead(II) compounds absorb at 245, 305 and $355 \mathrm{~nm}$ (1) and at 310 and $355 \mathrm{~nm}$ (2). Ptp shows emissions at 423 and $486 \mathrm{~nm}\left(\lambda_{\mathrm{ex}}=292 \mathrm{~nm}\right)$ which may be due to the intraligand $\left(\pi \rightarrow \pi^{*}\right)$ transition. Compound 1 exhibits main emissions at $421 \mathrm{~nm}$
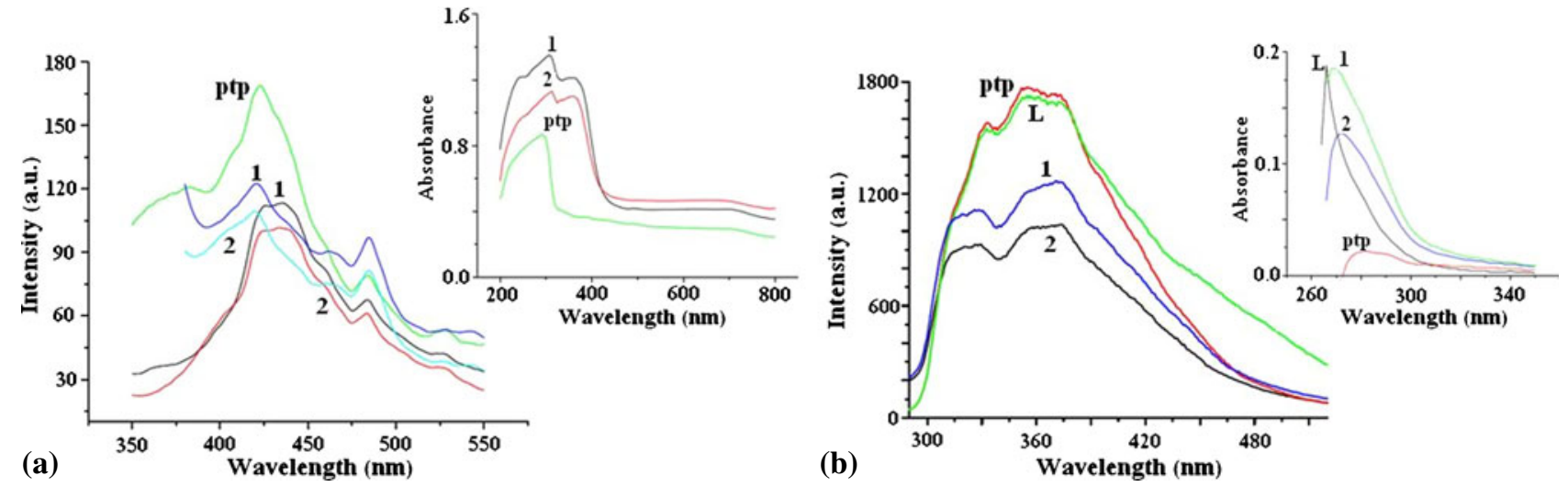

Figure 2. (a) Solid state fluorescence behaviours of ptp, $\mathbf{1}$ and $\mathbf{2}$, and inset: solid state absorption spectra of ptp, $\mathbf{1}$ and $\mathbf{2}$. (b) Fluorescence behaviours of L, ptp, 1 and $\mathbf{2}$ in DMF solutions, and inset: absorption spectra of L, ptp, 1 and $\mathbf{2}$ in DMF solutions. 


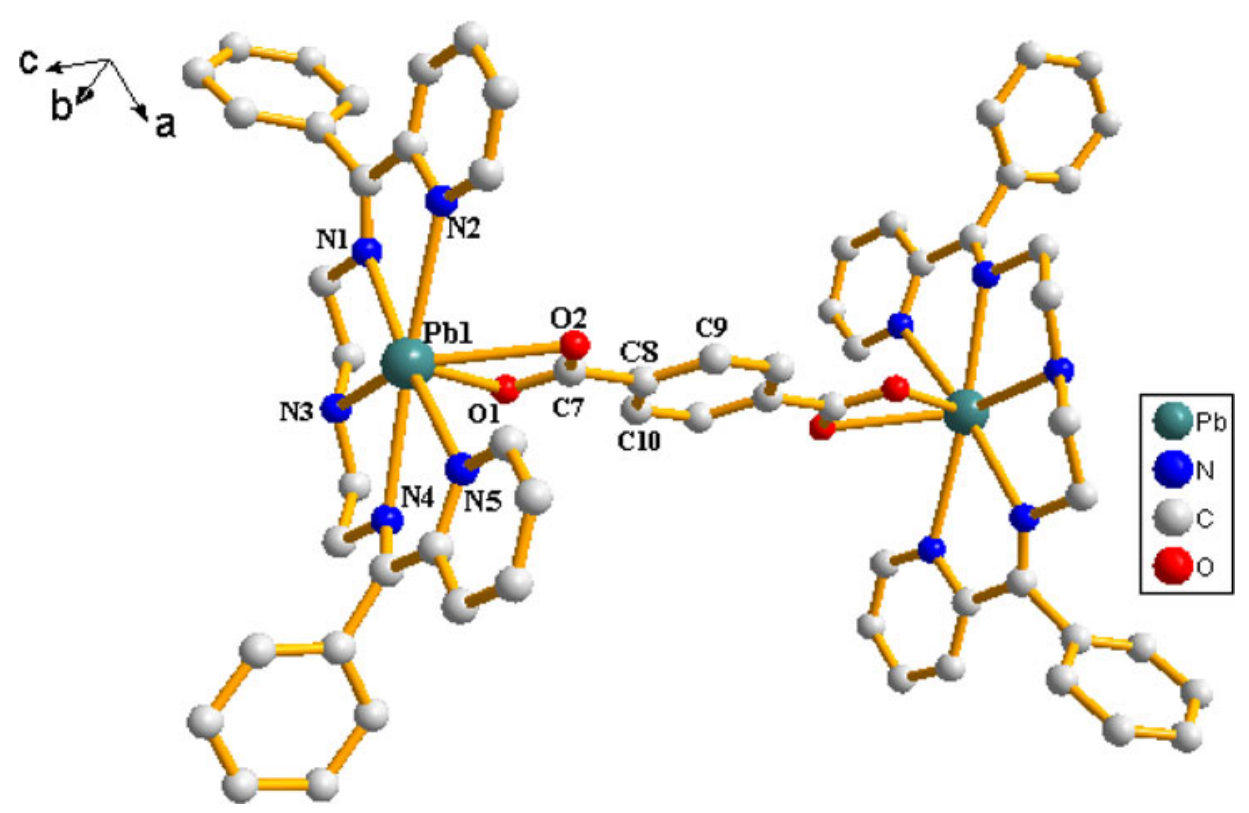

Figure 3. Molecular structure of $\left[\mathrm{Pb}_{2}(\mathrm{~L})_{2}(\mu-\mathrm{tp})\right]^{2+}$ in $\mathbf{1}$ showing hemidirected coordination environments of lead(II).

$\left(\lambda_{\mathrm{ex}}=305 \mathrm{~nm}\right)$ and $436 \mathrm{~nm}\left(\lambda_{\mathrm{ex}}=355 \mathrm{~nm}\right)$ with a weak emission band at $486 \mathrm{~nm}$, whereas 2 has main emissions at $420 \mathrm{~nm}\left(\lambda_{\mathrm{ex}}=310 \mathrm{~nm}\right)$ and $437 \mathrm{~nm}$ $\left(\lambda_{\text {ex }}=355 \mathrm{~nm}\right)$ with a weak emission at $487 \mathrm{~nm}$. The bands at ca. $420 \mathrm{~nm}$ in both 1 and 2 may be assigned to the ptp based intraligand $\left(\pi \rightarrow \pi^{*}\right)$ transition, whereas the band at ca. $435 \mathrm{~nm}$ may arise due to the ligand (L) based transition. ${ }^{38,39}$ The weak emission band at ca. $485 \mathrm{~nm}$ in both the complexes arises presumably due to either L or ptp based transition. Each band in solid state is red-shifted as compared to that in solution which may be due to intermolecular interactions arising from close proximity of the compounds in solid state leading to more stable excimer formation.

\subsection{Description of the crystal structures of $\left[\mathrm{Pb}_{2}(\mathrm{~L})_{2}(\mu-t p)\right]\left(\mathrm{ClO}_{4}\right)_{2}(\mathbf{1})$ and $\left[\mathrm{Pb}_{2}(L)_{2}(\mu-t p)\right]\left(P F_{6}\right)_{2}(2)$}

Structural analyses show that compounds $\mathbf{1}$ and $\mathbf{2}$ are made up of dinuclear cation $\left[\mathrm{Pb}_{2}(\mathrm{~L})_{2}(\mathrm{tp})\right]^{2+}$ with one tp bridge in a bis(bidentate) fashion and two pentadentate Schiff base chelators; two non-coordinated perchlorates (in 1) and hexafluorophosphates (in 2) are present as counter ions. Molecular structures of the dinuclear entities of these compounds are shown in figures 3 and $\mathrm{S} 1$. Selected bond distances and angles are given in table 2 . The dinuclear units in $\mathbf{1}$ and $\mathbf{2}$ lie about a crystallographic inversion centre located at the middle of the benzene ring of the tp bridge. The symmetry related metal centres have $\mathrm{Pb}$...Pb separations $11.465 \AA$ and $11.447 \AA$, respectively in $\mathbf{1}$ and $\mathbf{2}$.

Each lead(II) centre in $\mathbf{1}$ and $\mathbf{2}$ lies in an unsymmetrical seven-coordinated environment with a $\mathrm{PbN}_{5} \mathrm{O}_{2}$ chromophore, and is bound by five $\mathrm{N}$ atoms of $\mathrm{L}$ and two $\mathrm{O}$ atoms of tp dianion. The arrangement of Schiff base (L) and the tp dianion suggest a gap in the coordination geometry around the metal ion, occupied by a stereo-active lone pair of electrons on lead(II). The observation in shortening of the $\mathrm{Pb}-\mathrm{N}$ and $\mathrm{Pb}-\mathrm{O}$ bonds on the side of the lead(II) ion opposite to the position of the putative lone pair (table 2) corroborates the presence of the stereo-active lone pair. ${ }^{1,2}$ Based on the structural discussion by Shimoni-Livny et al., ${ }^{1}$ the coordination around the lead(II) centre in $\mathbf{1}$ and $\mathbf{2}$, may be regarded as hemidirected ${ }^{1,2,13,16}$ with a significant gap trans to the chelating $\mathrm{L}$ and tp ligands (figures 3 and S1) similar to a reported compound $[\mathrm{Pb}(\mathrm{DOTAM})]\left(\mathrm{ClO}_{4}\right)_{2} \cdot 4.5 \mathrm{H} 2 \mathrm{O}$ $($ DOTAM $=1,4,7,10$-tetrakis(carbamoylmethyl)$1,4,7,10$-tetraazacyclododecane). ${ }^{2}$

The value $\left(2.75^{\circ}\right.$ and $\left.2.66^{\circ}\right)$ of dihedral angles between carboxylate groups $(\mathrm{C} 7, \mathrm{O} 1, \mathrm{O} 2$ for $\mathbf{1}$ and $\mathrm{C} 21, \mathrm{O} 1, \mathrm{O} 2$ for 2) and benzene rings (C8, C9, $\mathrm{C} 10$ for $\mathbf{1}$ and $\mathrm{C} 18, \mathrm{C} 19, \mathrm{C} 20$ for $\mathbf{2}$ ) in $\mathbf{1}$ and $\mathbf{2}$ is in line with the quasi-planarity of the tp bridge upon coordination. Four five-membered and one fourmembered rings are formed around each metal ion in $\mathbf{1}$ and $\mathbf{2}$ by $\mathrm{L}$ and tp unit, respectively. Significant differences $[1.230(13) / 1.266(13) \AA$ (for 1) and $1.199(14) / 1.291(14) \AA$ (for 2)] are observed in values 
Table 2. Selected bond distances $(\AA)$ and bond angles $\left(^{\circ}\right)$ for $\mathbf{1}$ and $\mathbf{2}$.

Bond distances for 1

$\begin{array}{ll}\mathrm{Pb} 1-\mathrm{N} 1 & 2.682(8) \\ \mathrm{Pb} 1-\mathrm{N} 2 & 2.803(11) \\ \mathrm{Pb} 1-\mathrm{N} 3 & 2.567(8) \\ \mathrm{Pb} 1-\mathrm{N} 4 & 2.676(8) \\ \mathrm{Pb} 1-\mathrm{N} 5 & 2.820(11) \\ \mathrm{Pb} 1-\mathrm{O} 1 & 2.311(8) \\ \mathrm{Pb} 1-\mathrm{O} 2 & 2.720(8) \\ \mathrm{O} 1-\mathrm{C} 7 & 1.266(13) \\ \mathrm{O} 2-\mathrm{C} 7 & 1.230(13)\end{array}$

Bond angles for $\mathbf{1}$

$\begin{array}{lr}\text { O1-Pb1-N1 } & 84.5(3) \\ \text { O1-Pb1-N2 } & 100.3(3) \\ \text { O1-Pb1-N3 } & 74.2(3) \\ \text { O1-Pb1-N4 } & 82.4(3) \\ \text { O1-Pb1-N5 } & 99.5(3) \\ \text { N1-Pb1-N2 } & 57.5(3) \\ \text { N1-Pb1-N3 } & 65.4(3) \\ \text { N1-Pb1-N4 } & 131.3(3) \\ \text { N1-Pb1-N5 } & 170.4(3) \\ \text { N2-Pb1-N3 } & 122.9(3) \\ \text { N2-Pb1-N4 } & 171.2(3) \\ \text { N2-Pb1-N5 } & 113.0(3) \\ \text { N3-Pb1-N4 } & 65.9(3) \\ \text { N3-Pb1-N5 } & 124.1(3) \\ \text { N4-Pb1-N5 } & 58.2(3) \\ \text { O1-C7-O2 } & 122.5(12) \\ \text { O2-Pb1-N1 } & 103.0(3) \\ \text { O2-Pb1-N2 } & 71.9(3) \\ \text { O2-Pb1-N3 } & 124.9(3) \\ \text { O2-Pb1-N4 } & 104.1(3) \\ \text { O2-Pb1-N5 } & 73.9(3) \\ \text { O1-Pb1-O2 } & 50.8(2) \\ \end{array}$

O1-Pb1-N1 99.8(3)

$\mathrm{O} 1-\mathrm{Pb} 1-\mathrm{N} 2 \quad 74.3(3)$

$\mathrm{O} 1-\mathrm{Pb} 1-\mathrm{N} 3 \quad 83.5(3)$

O1-Pb1-N4 97.7(3)

$\mathrm{O} 1-\mathrm{Pb} 1-\mathrm{N} 5 \quad 84.1(3)$

$\mathrm{N} 1-\mathrm{Pb} 1-\mathrm{N} 2 \quad 123.9(3)$

$\mathrm{N} 1-\mathrm{Pb} 1-\mathrm{N} 3 \quad 171.1(3)$

$\mathrm{N} 1-\mathrm{Pb} 1-\mathrm{N} 4 \quad 112.7(3)$

$\mathrm{N} 1-\mathrm{Pb} 1-\mathrm{N} 5 \quad 57.7(3)$

$\mathrm{N} 2-\mathrm{Pb} 1-\mathrm{N} 3 \quad 64.9(3)$

$\mathrm{N} 2-\mathrm{Pb} 1-\mathrm{N} 4 \quad 123.3(3)$

$\mathrm{N} 2-\mathrm{Pb} 1-\mathrm{N} 5 \quad 66.2(3)$

$\mathrm{N} 3-\mathrm{Pb} 1-\mathrm{N} 4 \quad 58.4(3)$

$\mathrm{N} 3-\mathrm{Pb} 1-\mathrm{N} 5 \quad 131.1(3)$

N4-Pb1-N5 170.4(3)

$\mathrm{O} 1-\mathrm{C} 21-\mathrm{O} 2 \quad 122.6(13)$

$\mathrm{O} 2-\mathrm{Pb} 1-\mathrm{N} 1 \quad 71.7(3)$

O2-Pb1-N2 125.3(3)

$\mathrm{O} 2-\mathrm{Pb} 1-\mathrm{N} 3 \quad 104.7(3)$

O2-Pb1-N4 71.2(3)

O2-Pb1-N5 103.4(3)

$\mathrm{O} 1-\mathrm{Pb} 1-\mathrm{O} 2 \quad 51.0(3)$

of the $\mathrm{C}-\mathrm{O}$ bond distances for the bidentate chelating carboxylate bridges.

In the crystalline states, individual units of $\mathbf{1}$ and $\mathbf{2}$ are assembled through weak face-to-face $\pi \cdots \pi$ interactions among the adjacent pyridine rings $[\mathrm{Cg}(1)-\mathrm{Cg}(1)$ and $\mathrm{Cg}(2)-\mathrm{Cg}(2)$; table 3] of $\mathrm{L}$ resulting in $2 \mathrm{D}$ sheet structure (figure 4) parallel to crystallographic $a b$ plane.

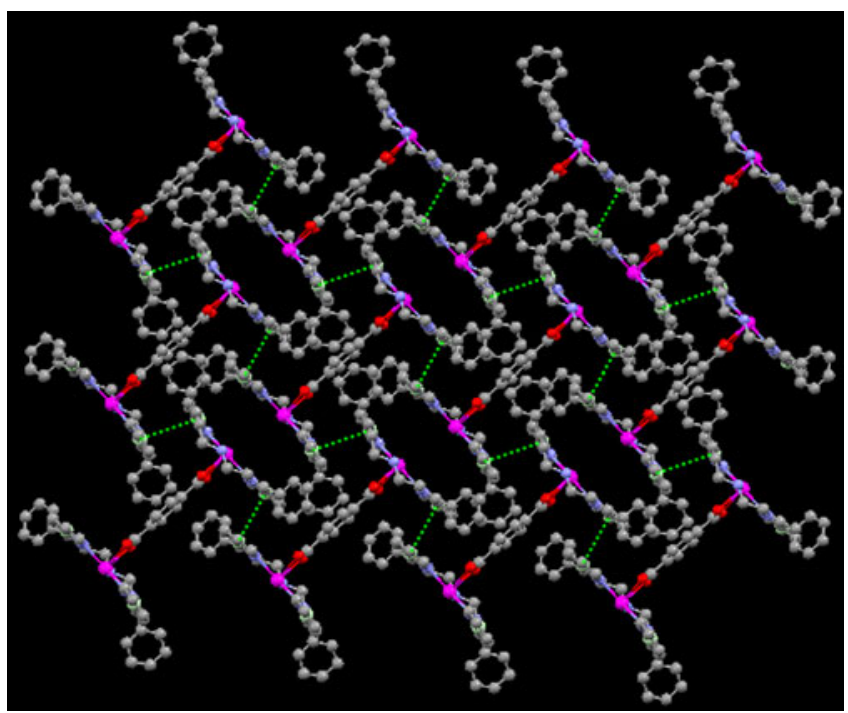

Figure 4. A view of $2 D$ sheet structure in $1 / 2$ formed through $\pi \ldots \pi$ stacking parallel to $a b$ plane.

\section{Conclusion}

Two tp bridged centrosymmetric dicationic dinuclear compounds of lead(II) in combination with a pentadentate Schiff base ligand are synthesized and Xray crystallographically characterized. The metal centres in both the compounds are linked through the dicarboxylate bridge in a bis(bidentate) fashion. The lead(II) centres in $\mathbf{1}$ and $\mathbf{2}$ have hemidirected heptacoordinated geometry with a stereo-active lone pair located at the opposite site of the Schiff base and tp. The compounds are examples of good luminous materials. We are now active in extending such work using paramagnetic $3 \mathrm{~d}$ ions like manganese(II), cobalt(II), nickel(II) and copper(II) in combination with different tailored polycarboxylates and organic blockers with varied denticities.

\section{Supplementary information}

Crystallographic data for the structural analyses have been deposited with the Cambridge Crystallographic

Table 3. $\pi \cdots \pi$ interactions $\left(\AA,^{\circ}\right)$ in $\mathbf{1}$ and $\mathbf{2}$.

\begin{tabular}{|c|c|c|c|c|c|}
\hline Compounds & $\mathrm{Cg}-\mathrm{Cg}$ & $\begin{array}{l}\mathrm{Cg}-\mathrm{Cg} \\
\text { distance }\end{array}$ & $\begin{array}{c}\text { Dihedral } \\
\text { angle }(i, j)\end{array}$ & $\begin{array}{l}\text { Perpendicular distances } \\
\text { between baricentres }(i, j)\end{array}$ & Slippage \\
\hline \multirow[t]{2}{*}{1} & $\mathrm{Cg} 1-\mathrm{Cg} 1^{\mathrm{a}}$ & $3.953(8)$ & 0 & $3.814(5)$ & 1.037 \\
\hline & $\mathrm{Cg} 2-\mathrm{Cg} 2^{\mathrm{b}}$ & $4.925(8)$ & 0 & $4.924(9)$ & 2.505 \\
\hline \multirow[t]{2}{*}{2} & $\mathrm{Cg} 1-\mathrm{Cg} 1^{\mathrm{c}}$ & $4.654(9)$ & 0 & $4.191(6)$ & 2.025 \\
\hline & $\mathrm{Cg} 2-\mathrm{Cg} 2^{\mathrm{d}}$ & $3.898(9)$ & 0 & $3.838(6)$ & 0.683 \\
\hline
\end{tabular}

Symmetry Codes: $\mathrm{a}=2-\mathrm{x}, 1-\mathrm{y}, 2-\mathrm{z} ; \mathrm{b}=1-\mathrm{x},-\mathrm{y}, 2-\mathrm{z} ; \mathrm{c}=1-\mathrm{x}, 1-\mathrm{y}, 2-\mathrm{z} ; \mathrm{d}=2-\mathrm{x},-\mathrm{y}, 2-\mathrm{z}$

[For 1: $\mathrm{Cg}(1)=\mathrm{N}(2)->\mathrm{C}(18)->\mathrm{C}(29)->\mathrm{C}(30)->\mathrm{C}(31)->\mathrm{C}(32), \mathrm{Cg}(2)=\mathrm{N}(5)->\mathrm{C}(1)->\mathrm{C}(2)->\mathrm{C}(3)->\mathrm{C}(4)->\mathrm{C}(5)$; for 2: $\mathrm{Cg}(1)=\mathrm{N}(1)->\mathrm{C}(1)->\mathrm{C}(2)->\mathrm{C}(11)->\mathrm{C}(3)->\mathrm{C}(4), \mathrm{Cg}(2)=\mathrm{N}(4)->\mathrm{C}(9)->\mathrm{C}(25)->\mathrm{C}(24)->\mathrm{C}(23)->\mathrm{C}(22)]$ 
Data Centre Nos. 899543 (1) and 899544 (2). Copies of this information can be obtained, free of charge from The Director, CCDC, 12 Union Road, Cambridge, CB2 1EZ, UK (fax: +44-1223-336033; e-mail: deposit@ccdc.cam.ac.uk or http://www.ccdc.cam.ac.uk).

The electronic supplementary information (figure S1) can be seen in www.ias.ac.in/chemsci.

\section{Acknowledgements}

Financial support from the Council of Scientific and Industrial Research (CSIR) and Department of Science and Technology (DST), New Delhi, India is gratefully acknowledged. SR is grateful to University Grants Commission (UGC), New Delhi, India. SC, SK and $\mathrm{KB}$ are grateful to the CSIR for fellowships. Authors also acknowledge the use of DST-funded National Single Crystal X-ray Diffraction Facility at the Department of Inorganic Chemistry, Indian Association for the Cultivation of Sciences (IACS), Kolkata, India for crystallographic study.

\section{References}

1. Shimoni-Livny L, Glusker J P and Bock C W 1998 Inorg. Chem. 371853

2. Hancock R D, Reibenspies J H and Maumela H 2004 Inorg. Chem. $\mathbf{4 3} 2981$

3. Magyar J S, Weng T C, Stern C M, Dye D F, Rous B W, Payne J C, Bridgewater B M, Mijovilovich A, Parkin G, Zaleski J M, Penner-Hahn J E and Godwin H A 2005 J. Am. Chem. Soc. 1279495

4. Andersen R J, Targiani R C, Hancock R D, Stern C L, Goldberg D P and Godwin H A 2006 Inorg. Chem. 45 6574

5. Liu Q-Y and Xu L 2006 Eur. J. Inorg. Chem. 20061620

6. Yang J, Li G-D, Cao J-J, Yue Q, Li G-H and Chen J-S 2007 Chem. Eur. J. 133248

7. Ding B, Liu Y Y, Wu X X, Zhao X-J, Du G X, Yang E-C and Wang X G 2009 Cryst. Growth Des. 94176

8. Fan S-R and Zhu L-G 2007 Inorg. Chem. 466785

9. Zhao Y-H, Xu H-B, Fu Y-M, Shao K-Z, Yang S-Y, Su Z-M, Hao X-R, Zhu D-X and Wang E-B 2008 Cryst. Growth Des. 83566

10. Wang X-L, Chen Y-Q, Zhang J-X, Liu G-C, Lin H-Y and Tian A-X 2010 Z. Anorg. Allg. Chem. 636830

11. Wibowo A C, Vaughn S A, Smith M D and zur Loye H-C 2010 Inorg. Chem. 4911001

12. Yang J, Ma J-F, Liu Y-Y, Ma J-C and Batten S R 2007 Inorg. Chem. 466542
13. Zhang L, Li Z-J, Lin Q-P, Qin Y-Y, Zhang J, Yin P-X, Cheng J-K and Yao Y-G 2009 Inorg. Chem. 486517

14. Tan Y-X, Meng F-Y, Wu M-C and Zeng M-H 2009 J. Mol. Struct. 928176

15. Yang J, Ma J-F, Liu Y-Y, Ma J-C and Batten S R 2009 Cryst. Growth Des. 91894

16. Hu M-L, Morsali A and Aboutorabi L 2011 Coord. Chem. Rev. 2552821

17. Chattopadhyay S, Bhar K, Khan S, Mitra P, Butcher R J and Ghosh B K 2010 J. Mol. Struct. 966102

18. Chattopadhyay S, Bhar K, Choubey S, Khan S, Mitra P and Ghosh B K 2012 Inorg. Chem. Commun. 1621

19. Lei X, Shang M, Patil A, Wolf E E and Fehlner T P 1996 Inorg. Chem. 353217

20. Rao C N R, Natarajan S and Vaidhyanathan R 2004 Angew. Chem. Int. Ed. 431466

21. Zhang L, Qin Y-Y, Li Z-J, Lin Q-P, Cheng J-K, Zhang J and Yao Y-G 2008 Inorg. Chem. 478286

22. Zhang K-L, Chang Y, Zhang J-B, Deng Y, Qiu T-T, Li L and Ng S W 2012 Cryst. Eng. Comm. 142926

23. Allendorf M D, Bauer C A, Bhaktaa R K and Houk R J T 2009 Chem. Soc. Rev. 381330

24. Mao J-G, Wang Z and Clearfield A 2002 Inorg. Chem. 416106

25. Vigato P A, Tamburini S and Bertolo L 2007 Coord. Chem. Rev. 2511311

26. Karmakar T K, Chandra S K, Ribas J, Mostafa G, Lu T-H and Ghosh B K 2002 Chem. Commun. 2364

27. Sarkar B N, Bhar K, Chattopadhyay S, Das S, Mitra P and Ghosh B K 2010 J. Mol. Struct. 96335

28. Bhar K, Khan S, Costa J S, Ribas J, Roubeau O, Mitra P and Ghosh B K 2012 Angew. Chem. Int. Ed. 1242184

29. Verdaguer M, Gouteron J, Jeannin S, Jeannin Y and Kahn O 1984 Inorg. Chem. 234291

30. Sheldrick G M 1996 SAINT, V4 software reference manual Siemens analytical X-ray systems (Madison, WI: USA)

31. Sheldrick G M 1996 SADABS program for empirical absorption correction of area detector data (Germany: University of Göttingen)

32. Sheldrick G M 2008 Acta Crystallogr. A 64112

33. Spek A L 1999 PLATON molecular geometry program (The Netherlands: The University of Utrecht, Utrecht)

34. Macrae C F, Edgington P R, McCabe P, Pidcock E, Shields G P, Taylor R, Towler M and van de Streek J 2006 J. Appl. Cryst. Allogr. 39453

35. Geary W J 1971 Coord. Chem. Rev. 781

36. Nakamoto K 2009 Infrared and Raman spectra of inorganic and coordination compounds (New Jersey: John Wiley) Part B, sixth edition

37. Lever A B P 1984 Inorganic electronic spectroscopy (New York: Elsevier) second edition

38. Lakowicz J R 2006 Principles of fluorescence spectroscopy (New York: Springer) third edition

39. Wang X-L, Chen Y-Q, Gao Q, Lin H-Y, Liu G-C, Zhang J-X and Tian A-X 2010 Cryst. Growth Des. 102174 